\title{
土砂災害教育のあり方とその効果・波及に関する研究*
}

\section{Research on Practical Education of Sediment Disasters and its Ripple Effect*}

\author{
金井昌信** ・片田敏孝*** ・望月 準**** \\ By Masanobu KANAI**, Toshitaka KATADA*** and Jun MOCHIZUKI****
}

1. はじめに

\section{（1）土砂災害の避難対策の問題点}

自然災害発生危険時には，住民は周辺状況の変化や行 政からの情報をもとに，災害発生前に避難することが必 要となる. しかし, 現状において, 多くの住民は, 周辺 状況の変化を自らで察知することよりも，行政からの情 報に依存している傾向にある ${ }^{12}$ 2). そのため, 行政は住民 の情報ニーズに応えるために, 災害時の情報伝達のあり 方を検討している ${ }^{3)}$. しかし, 豪雨由来の土砂災害の場 合, 他の自然災害と比較して, 行政にとっては, 避難情 報が非常に出しにくい状況にあるといえる. その理由と して, 局所的な豪雨に関する予知情報の精度が不十分で あること，土砂災害の発生メカニズムが非常に複雑で普 遍的な予兆現象が見当たらないことが挙げられる ${ }^{4)}$.つ まり，避難情報が出ていない場合でも災害発生の危険性 があるといえ，逆に，避難情報が出ていたとしても，外 れてしまうこと（空振り）が多々生じる. そのため, 住 民は，行政からの情報に依存しつつも，その情報の精度 が不確かなために, 情報を軽視する傾向にある.そして， このように避難情報が不確かなことと，国土の大半が山 地であるために全国各地に土砂災害危険箇所が多数存在 することから，土砂災害はわが国において最も犠牲者の 多い自然災害となっている.

そこで, 土砂災害による犠牲者を減少させるためには, 防災教育等によって住民に避難を促すとともに，住民自 らが判断して避難することのできる体制をつくることが 必要であると考えられる．幸いにも，土砂災害発生危険 時に住民が取得することのできる情報としては，普遍的 な予兆現象はみられないものの, その地域特有の予兆現 象が存在することが多い，そのため，それらの情報を地 域住民で共有し，地域単位での自主避難体制をつくるこ とで, 行政に頼らない土砂災害対応を行うことが可能で あると考えられる5).

\footnotetext{
*キーワーズ: 防災計画, 意識調査分析

**正会員, 博(工), 群馬大学工学部建設工学科

(群馬県桐生市天神町1-5-1, TEL:0277-30-1652,FAX:0277-30-1601)

***正会員, 工博, 群馬大学工学部建設工学科

*****学生員, 群馬大学大学院工学研究科
}

\section{(2) 目的}

上記のような問題意識のもと，本稿では，土砂災害を 事例に，災害発生危険時における住民の自主避難を促す ための防災教育のあり方を提案する. 具体的には, まず, 住民のリスク認知や土砂災害対策に関する既存研究の知 見をもとに, 効果的な防災教育の実施方法について示寸. そして，その具体的な内容として，地域住民に伝えるべ き情報と，地域で㥶行することのできる土砂災害対策の 一つとして地域住民が主体となった自主避難体制につい ても提案する. また, 土砂災害発生リスクの高い群馬県 みなかみ町を対象に，本稿で提案する防㷋教育を実践す ることによって，その実施効果を検証する．なお，本稿 で実践した具体的な取り組みの内容は，地城住民を対象 に, “土砂災害を考える愁談会”を定期的に開催し，その 場において住民が自主避難するための指標となる防災マ ップを作成するとともに，それを用いた避難体制を確立 することである.

一方，このような地域防災に関寸る取り組みは，社会 実験としてある一地区を対象に実施されることが多く， そのため, その効果は対象地区内に限定されてしまうこ とが多いのわ。しかし，土砂災害の危険地域は全国各地に 多数存在するため, 一地区での取り組みを地区内にとど めたままにせず，その成果を効率的に波及させることに より, 地域全体の自主防災力の向上を図ることが重要と 考えられる. そこで本研究では，モデル地区での取り組 み実施効果を, モデル地区に隣接する地区 (隣接地区) 一波及させることにより，地域全体の自主防災力の向上 を促すための効率的な波及施策の検討も行う.

そのため, 本稿では, “提案する防災教育の効果” と“そ の効果の効率的な波及施策” の二点を検討するために, 取り組みを実施したモデル地区住民の防災意識や備えの 行動の変化を把握するだけでなく, 直接的には取り組み を実施していない隣接地区住民の変化を計測し，取り組 み前後における両者の変化を比較することにより, 取り 組み実施効果と地域間波及の実態を把握する.

\section{(3) 本研究の位置づけ}

本研究の取り組みは，ある地域を研究フィールドとし て固定し，そこで顕在化している問題に対して，既存の 
知を援用した対策を実践し，その効果を検証していくと ともに，その対策を実践していく中で生じる新たな問題 に対して，その地域でのそれまでの取り組みを踏まえた 新たな対策を実施したものである.つまり，本研究はあ る地域に停留し，そこで知の社会還元・検証を繰り返す ことによって地域に学ぶアプローチである Social Co-learning の防災分野における実践である：Social Co-learning は, 平成 17 年 1 月に神戸で実施された国連防 災世界会議 ${ }^{8}$ において, 「参加型リスク・コミュニケーシ ヨン」の重要性が指摘されたなかで, その実践的研究ア プローチとして提晿されたものである. 現在はまだこの ような研究アプローチによる事例は少ないものの, 地域 の問題に対して地域固有の知を活かした対策を考えて いくというアプローチは，“住民自らの積極的な対応に よる地域防災力の向上”を政策として謳っているわが国 の防災に大きく寄与するものであると考えられる.

\section{2. 土砂災害に関する防災教育の提案}

まず，従来までの防災教育の実施方法やその内容に関 する問題点や，住民のリスク認知に関する研究 ${ }^{19}$ ９，11)や 土砂災害対策に関する知見 4 ) 5 を踏まえて, 土砂災害に対 する防災教育の実施手法を提案する. さらに, その具体 的な内容として地域住民に伝えるべきメッセージと，地 域で実行可能な土砂災害対策の一つとして地域住民が主 体となった自主避難体制のあり方について示す.

\section{（1）防災教育手法の検討}

従来まで害施されている防災教育は，ハザードマップ の配布や, 講演会や講習会などの講話によって, 災害情 報の送り手である行政や専門家から，受け手である地域 住民に一方的に情報を提供するような取り組みが多か った. しかし，そのような情報の提供方法，すなわち一 方的な防災教育では, 本来であれば最も教育対象とすべ き災害に対して興味・関心のない住民が，それらの情報 に見向きもしないことが考えられる.つまり，配布され たハザードマップを見ることはなく, 講演会を実施した としても参加しない.これは洪水ハザードマップの公表 効果に関寸る研究 ${ }^{10)}$ でも指摘されている問題である.

そこで, 本研究ではこのような従来までの一方的な防 災教育に対し，情報の送り手である行政や専門家と情報 の受け手である住民とが，災害に関する情報をお互いに やりとりする中で, 地域の防災を考え, 実際に備えの行 動を実行することを促す, 双方向の参加型防災教育手法 (本研究では，これを従来までの “一方的な防災教育” に対して，“双方向の防災教育”とする）を提案する. 具体的には，地域住民を対象に “土砂災害を考える愁談 会”を定期的に開催し, その会において, 専門家は災害
情報を提供するだけでなく，その提供した情報に対する 地域住民の反応を見ながら，次に提供すべき情報や実行 を促すべき対策を検討することを通して，住民と一緒に 地域の防災対応を検討していくというものである.

なお，このようにあるリスク事象に関して，情報の送 り手と受け手との間でリスクに関する様々な情報をや りとりすることを通して，そのリスクに対する相互理解 を深め, よりよい対応行動を引き出すことを目的とした コミュニケーションは, リスク・コミュニケーション ${ }^{11)}$ と呼ばれ, 近年, 様々な防災研究においてその概念が用 いられている. ここで, これまで実施されてきたリス ク・コミュニケーションを概観すると, リスクに対する 理解を促進することに主眼をおいた取り組みが多く，具 体的な行動を実行することを地域住民に促すことがで きた事例はあまり見当たらない，しかし，自然災害を対 象とした場合，地域住民それぞれが災害対策を実行しな ければ問題を解決することはできないものといえ，その ため, 具体的な対策の実行を促すことが, 自然災害を対 象としたリスク・コミュニケーションには必要不可欠で あるといえる.

以上のような認識のもと, 本稿では, コミュニケーシ ヨンの結果として, 地域住民に具体的な行動の実行を促 すために, 次の二点を踏まえたコミュニケーションを実 施することを提案する. まずは, 地域住民に対して, 災 害に備えた行動をとることは自らの責務であることを 自覚してもらうことが必要となる. そのためには，これ までの防災教育のようにただ “逃げろ” と繰り返すので はなく，なぜ自分たちで対応しなければならないのかを 納得することはできるような防災教育を実施すること が必要となる，そのように災害対応を自ら実行する自覚 を地域住民が持ったうえで, 災害に備えた行動を実行す ることを促すことが必要となるといえる. この際にも， これまでのょうに漠然とした対応行動を提示するので はなく，地域住民にとって具体的かつ実行可能であると 感じられる対策を提案することが重要と考える.

以下に，地域住民に自らが災害に備えることを自覚し てもらうための土砂災害を対象とした場合の防災教育 の内容と, 具体的な対応策としての地域住民による自主 避難体制の確立について詳述する.

\section{（2）土砂災害に対する防災教育内容の検討}

まず，地域住民自らが災害に備えなければならないこ とを理解し納得してもらうためには，土砂災害に関する 防災教育として, 次に挙げる（a）から（d）までの情 報を住民に伝えることが必要であると考える.

\section{（a）敵を知り，己を知る}

従来の防災教育では，災害とはどのように発生するの か, 発生した場合には地域にどの程度の被害が生じるの 
か，などといったように，災害について知ること（敵を 知ること）を住民に対して促してきた.これは発生メカ ニズム等の土砂災害に関する現象について梁く理解して もらい，災害に対する認知の曖昧さを解消するという点 において重要であるものの, 知識の提供だけでは避難に 結びつかないことがいくつかの被災地調査によって指摘 されている ${ }^{1)}$ 。つまり, 災害に備えるためには, 災害に ついて理解するだけでなく, 災害に対峙した際の自分自 身 (人間) の心理・行動特性を知る（己を知る）ことが 重要であるといえる，具体的には，災害をイメージする 際に，自分が被害に遭いたくないがために，災害リスク を過小に見積もろうとすることや，災害時にはいざ危険 な状況になったとしても，なかなか避難することができ ないといった人間の心理特性を理解してもらう.

\section{（b）防災施設に対する過剩な依存心の解消}

新たな宅地開発等に伴い，土砂災害危険箇所は年々増 加しており，全ての土砂災害危険箇所を対策工事によっ て安全にしていくには膨大な時間と費用が必要となる. そのため, 現在の困窮する地方財政ではすべての危険地 域に防災施設を建設することは不可能であることを理解 してもらう．また，防災施設を建設したとしても，防災 施設には想定外力が存在するため, それを超える規模の 災害には対応できないことに対する理解を促す。

（c）行政からの情報に対する過剩な依存心の解消

災害対応は行政がやってくれるものだという思いが強 い住民が多数存在している ${ }^{2)}$. しかし，役場などの行政 機関の人々も，地域住民と同様，実際に災害を経験して いる訳ではないので，災害時のすべての対応を円滑に行 うことは不可能であるといえる. また土砂災害は，他の 自然災害に比べて災害発生の不確実性が非常に高いため, 災害発生危険時にいつまでも行政からの情報を待つとい った消極的な姿勢では，避難が間に合わない場合も考え られる. そのため, すべてを行政に委ねても不可能であ ること, また土砂災害は予知の難しい災害なので, 適切 なタイミングで避難勧告が発令されることも難しいこと を認識してもらう。.

\section{(d) 自助 $\cdot$ 互助の必要性の認識}

以上の（a）から（c）までのポイントを踏まえ, 災 害時の対応は他人任せにせず，災害が発生した場合を想 定して,住民ひとり一人に自分が出来ること（自助），地 域のみんなで対応しなければならないこと（互助）を認 識してもらう.

\section{（3）地域住民による自主避難体制の検討}

次に，地域で害行することのできる具体的かつ現実的 な土砂災害対策の一つとして，地域住民が主体となった 自主避難体制を確立することを提案する．以下にその具 体的な手順について示す.

\section{（a）地域住民の知識の共有化}

土砂災害には，地域特有の予兆現象がみられる場合が 多く，また，それらの知恵は言い伝えなどとして地域に 残っていることが多い，そのため，それらの情報を集約 し, 地域住民間で共存することによって, 自主避難の判 断材料とすることを提案する. 具体的には，土砂災害の 予兆現象（沢の水が濁り始める,山鳴りがする等）を, 住 民から集め，専門家の意見を取り入れた八ザードマップ を作成することにより，地域住民の自分達が住む地域に 対するさらなる理解を図る. そのことにより，普段から 常に山や自然に目を配り注意を払うようになれば，予兆 現象を発見した場合, 早い段階での自発的な防災対応行 動が可能となる．また，このように検討した内容を八ザ ードマップとして形にしておくことにより，後世にその 情報を伝承することが可能となるものと考えられる.

\section{（b）地域住民による避難体制の確立}

その発生に関して不確害性の高い土砂災害への備え として，地域住民全員が無事に避難するための住民主導 型の自主避難体制を確立することを提案する. 具体的に は, (a ) で示したハザードマップに記載した予兆現象を 土砂災害発災危険時に地域住民それぞれが察知した場合， 行政からの情報を待たずに住民自らの判断で自主避難を 開始するという住民主導型の体制の確立を促す.

\section{3. 実験の概要}

\section{（1）実験概要}

ここで，本研究の主要な目的である “第 2 章で提案し た防災教育の効果” と “その効果の効率的な波及施策” を検討するために行った実験の概要について述べる.

まず，対象地域内のある集落（モデル地区）の住民に 対してのみ, 本研究でその必要性を提案している双方向 の防災教育として “土砂災害を考える懇談会”を開催し, それを通して，2章において提案した情報をモデル地区 住民一提供することにより，住民による自主避難体制の 確立を目指す，そして，㨸談会による防災教育の実施効 果を検証するために，モデル地区住民と，対象地域内で も㦝談会を実施していない集落（隣接地区）に居住する 住民のそれぞれを対象に，㼟談会の実施前後において複 数回のアンケート調査を実施し, その結果を比較する.

また，モデル地区での取り組み効果を隣接地区へ波及 させるために，本実験ではモデル地区での取り組みを紹 介するチラシなどを隣接地区住民には配布する.この理 由としては，ほぼ同レベルの土砂災害リスクにさらされ ているモデル地区と隣接地区において，モデル地区だけ で取り組みを行っていることを，隣接地区住民が知るこ とによって，「モデル地区ではこのような取り組みをし ているのに，うちは大丈夫なのか?」という不安を抱か 
せることになり，それにより，隣接地区住民の防災意識 が向上するものと考えたからである. すなわち, 隣接地 区では，双方向の防災教育は行わず，従来のような一方 的な情報提供のみを行うが，提供する情報は工夫するも のとする. そして, チラシや住民間の口頭伝達によって, モデル地区の取り組みを知った隣接地区住民と，モデル 地区での取り組みを知らない隣接地区住民のアンケー 卜結果を比較することで，このような取り組みの実施効 果の波及に関する知見を得ることとする．それぞれの地 区に対して，実施した取り組みの内容は図一 1 に示寸通 りである.

\section{（2）実験効果に関する仮説}

このような取り組みによって，以下のような効果が期 待できるものと考える. まず，モデル地区住民について は, 懇談会を通した双方向の防災教育を実施したことに より，防災意識の向上，備えの行動の新規実行率が高ま るものと期待される. また，隣接地区住民については, モデル地区住民ほどの変化は期待できないものの, モデ ル地区での取り組みを知った住民の方が知らない住民 よりも防災意識が向上するものと期待される.

\section{（3）対象地域の概要}

本研究での取り組みは, 群馬県みなかみ町を対象に実 施した. みなかみ町は山間部に位置し, その地形的特色 から多くの土砂災害危険箇所が存在する地域である. 豪 雨や雪解けの水などによる土砂災害の被害を受けやす く、過去に甚大な被害を被っている. 直近の災害では, 平成 10 年に 8 月末豪雨 $(8$ 月 26 31 日, 半壊家屋 2 件, 一部破損 1 件, 床上浸水 32 件, 床下浸水 161 件), 平成 14 年 7 月豪雨 (7月 10 11 日, 家屋被害 7棟) の 2 つが あり，幸いにも人的被害は無かったが，家屋は大規模な 被害を受けている.

なお，本取り組みでは群馬県みなかみ町に存在する粟 沢・綱子・大穴の 3 つの集落を対象地域に選定し, この うち粟沢をモデル地区，綱子・大穴を隣接地区とした.

\section{（4）調査概要}

モデル地区における㤅談会実施効果と，モデル地区か ら隣接地区への効果の波及の程度を計測するために, 本 研究では図一 1 に示す実験フローのもと, アンケート調 査を実施した. 表一 1 にその概要を示寸. 調査項目とし ては，土砂災害対応に関する意識（態度項目）と日頃の 備え（行動項目）に関する問を共通項目として設定し, それらの項目を比較することで効果を計測した.

\section{（5）実験の具体的内容}

以下にそれぞれの地区に対して実施した取り組みを

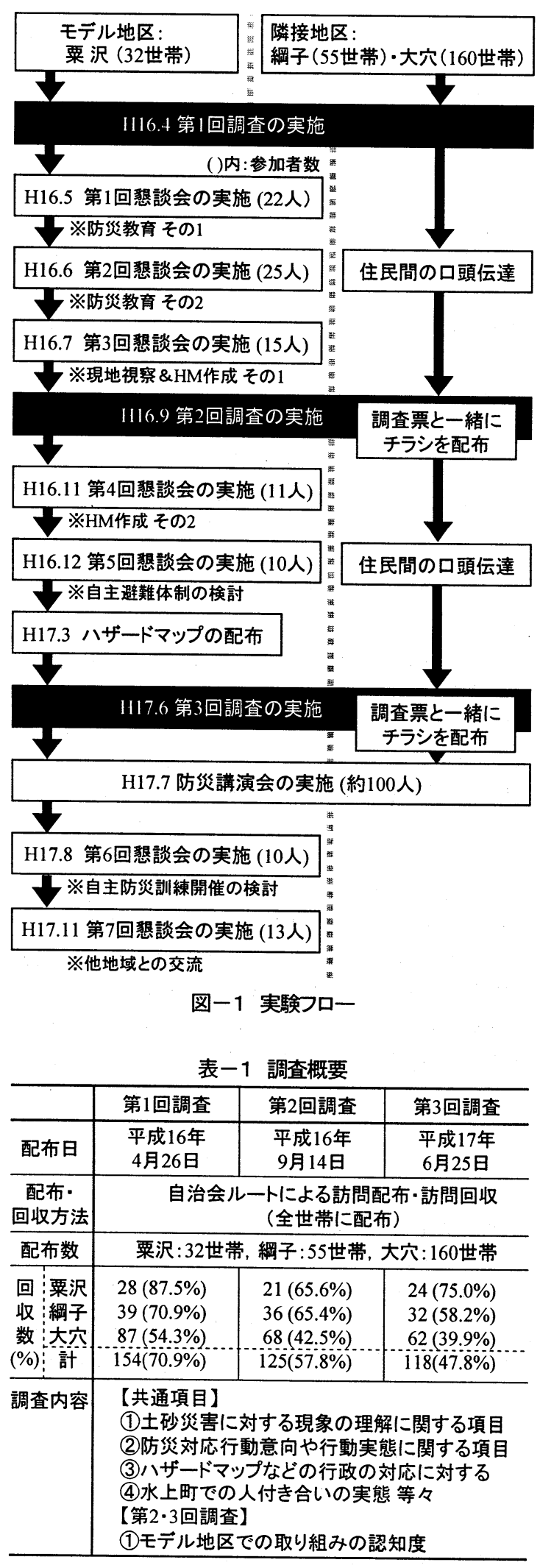

示す. 


\section{（a）モデル地区での取り組み}

モデル地区では，地区住民（32 世帯）を対象に計7回 の懇談会を実施した.この懇談会では，2章で提案した 土砂災害防災教育を実施することにより，住民間での知 識の共有, 自主避難体制の確立を住民と一緒に検討した。 各回の懇談会で実施した詳細な内容を以下に示寸。

まず，第 1 回懇談会では，粟沢地区に起こりえる土砂 災害についての説明を行うとともに，土砂災害の特徵と して普遍的な予兆現象がみられないために, 行政からの 情報はあてにできないことを説明した. またいざという ときになかなか逃げられない人間の心理特性について 話をした.

第 2 回懇談会では，土砂災害に関する様々な予兆現象 について話をした. モデル地区の粟沢では平成 10 年に 土石流が発生し, 主要道が閉鎖される被害をうけていた ため，その当時の様子を住民同士で話し合ううちに，そ れらの予兆現象を何らかの方法により地域内で共有す ることを提案した.

第 3 回懇談会は, 懇談会を行う前に, 地域内の土砂災 害危険箇所を住民と一緒に視察した。 その視察の結果を 踏まえて，地域の知識を共有するために，防災マップの 作成を始めた. 防災マップの作成は第 4 回懇談会におい ても引き続き議論した.

そして, 第 5 回愳談会では, 完成した防災マップを用 いて，いざというときに地域住民全員が無事に避難する ことができるようにするために, 自主避難体制のあり方 について検討した. ここでは, 自主避難勧告発令の基淮 として，地域の区長を中心とした機械的な判断基準を決 めることを促した.

第6 回懇談会は，実際に防災マップが配布された後に 実施した. ここでは，このような取り組みを通して高い 水淮となった危機意識を風化させないために，地域で自 主避難訓練を開催することを決定し，その実施方法等に ついて詳細に検討した.

最後に第 7 回懇談会では, 粟沢地区で実施していたよ うな取り組みをすでに 20 年近く続けている群馬県棒名 町社家地区 ${ }^{5)}$ の防災担当者をお呼びして，地域で長く防 災の取り組みを続けていくための工夫などを教えても らい, 粟沢地区での今後の取り組むに反映するためには どうした良いかを議論した。

\section{(b) 隣接地区への波及}

隣接地区への波及に関する取り組みとしては, モデル 地区での取り組みを広報やチラシ，住民間の口頭伝達に よって隣接地区住民一周知を促した. また, 平成 17 年 7 月には，対象地域であるみなかみ町の全町民を対象とし た防災講演会を実施し, 先進的な自主防災の取り組み例 としてモデル地区での取り組みを紹介した.

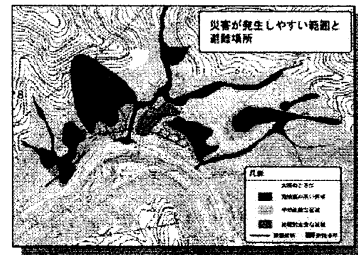

(i)土秒災害危除䓟所

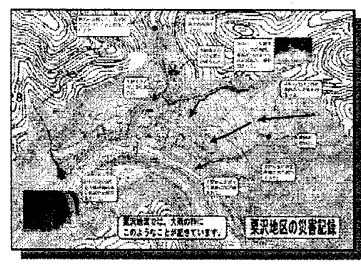

(iii)聥去の災言の記㘧

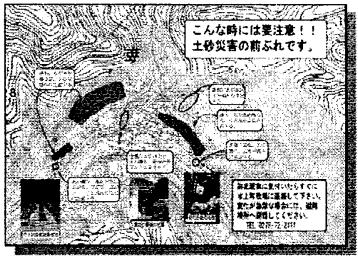

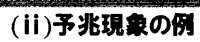

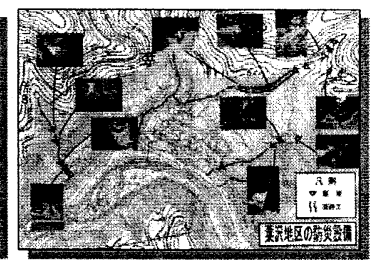

(iv)防災設借状況
図ー2 烈談会で作成した粟沢地区の防災マップ

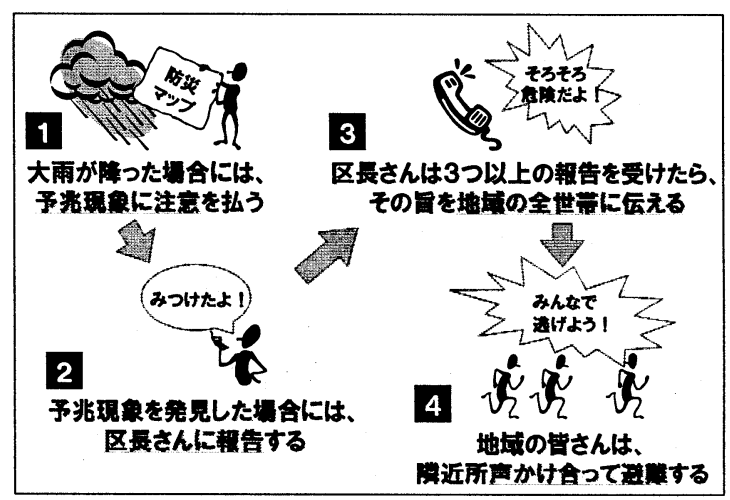

図ー3 懇談会で決定した粟沢地区の自主避難ルール

\section{（6）モデル地区での成果}

ここでは，モデル地区で害施した懇談会を通して得ら れた成果についてそれぞれ以下にまとめる.

(a) 防災マップ

懇談会を通して作成した防災マップを図ー 2 に示す. マップは全部で 4 つあり，まず( i )は，土砂災害の専門 家が現地を視察して危険度を評価し，それを色で塗り分 けるとともに，地域内の避難所とそこまでの避難経路を 示したものである. (ii)は, 懇談会で地域住民から聞き 取った先祖から言い伝えられている予兆現象を取りまと めたものである. (iii)は, 粟沢地区の災害記録として, 直近に発生した平成 10 年, 12 年の土砂災害時の状況を とりまとめたものである. (iv)は, 粟沢地区の防災設備 として, 行政によって整備された防災施設を示したもの である.

（b）自主避難ルール

懇談会を通して作成した防災マップを用いた粟沢地区 の自主避難ルールについて，図ー3に示す。この図にあ るように, 大雨などの土砂災害発生危険時には，地区の 全住民がセンサーとなって地域内の状況に目を配り，予 兆現象を発見した際にはすぐに区長に報せ，区長は地区 
住民から 3 つ以上の情報が報告された時点で速やかに全 住民に対してその旨を報せる，そして住民はその報せを もとに隣近所に声をかけ合って避難する，という仕組み を作った. ここで, 3 つ上上の報告を受けたらその内容 にかかわらず全住民にその状況を報せることにしたのは， 避難情報の発信基準に個人（区長）の判断を介してしま うと，正常化の偏見などにより，的確なタイミングで情 報を発信することができない可能性があるため，できる だけ機械的な判断基準を設けた.

\section{（c）自主避難訓練}

㦝談会を通して地域住民の防災意識は啓発されたとし ても，時間の経過とともにその意識も風化してしまう可 能性が高い，そこで，地区の住民主導で自主避難訓練を 毎年の地区の恒例行事とすることを決定した. 詳細につ いては現在，粟沢地区住民の間で議論をしている.

\section{4. 効果の計測}

\section{（1）基礎分析}

まず，本分析で用いたデータの個人属性について示す. ここでの分析は全て第1 回調査の結果のみを用いている.

図ー4にアンケート回答者の地区別年齢構成を示す. 調査に協力してくれたほとんどの世帯は，世帯主がアン ケートに回答していたこともあり，全ての地区で 60 歳 以上の住民の割合が半数以上となっている. この結果か ら，対象地域の多くの世帯が高齢者と同居していること がわかる。

次に, 図一 5, 図一6に, 地区別の土砂災害への関心, 土砂災害の発生やその被害に対する不安を示す。これよ り, 粟沢地区 (モデル地区) で, 他の 2 地区よりも, “と ても関心がある”, “とても不安”という住民の割合が低 くなっているものの，3 地区共にほぼ全ての住民が土砂 災害に関心があり，またその発生や被害に不安を感じて いることがわかる．また，年齢別に土砂災害への関心， 不安を集計した結果，年齢の違いによる差はほとんど見 られなかった。

最後に, 日頃からの人付き合いの程度として, 表一 2 に地区別日頃からの付き合いがある人の有無を示す。こ れより，居住地区内に日頃からの付き合いがある人がい る割合が高くなっているのはもちろんであるが, 粟沢地 区住民のうち，綱子地区，大穴地区に日頃からの付き合 いのある人がいる割合は，それぞれ $47.8 \%, 43.5 \%$ となっ ている. また, その逆で, 綱子地区住民のうち, 粟沢地 区に日頃からの付き合いのある人がいる割合は $48.4 \%$, 同じく大穴地区住民のうち, 粟沢地区に日頃からの付き 合いのある人がいる割合は $31.3 \%$ となっている。これよ り，3 地区は隣接する地区であることから，日頃から他 地区の住民との交流を持っている住民が比較的多いこ

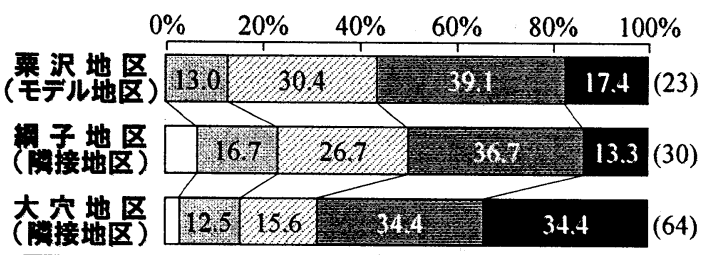

$\square 30$ 代圆40代回50代園60代田代以上

図-4 回答者の年齢構成(第 1 回調查結果)

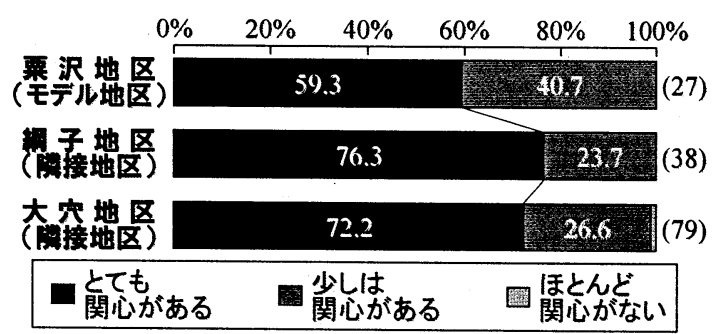

図-5 土砂災害への関心(第1回調查結果)

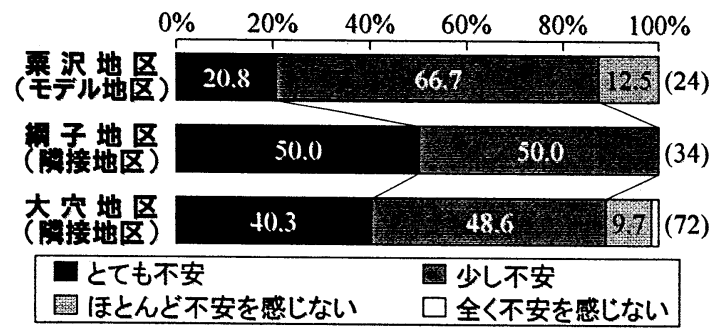

図一6 土砂災害の発生·被害に対する不安(第1回調査結果)

表-2 日頃から付き合いがある人の有無(第1回調查結果)

\begin{tabular}{|c|c|c|c|c|}
\hline & \multicolumn{3}{|c|}{ 日瞰からの付を合いがある人の有告 } & \multirow[b]{2}{*}{$(\mathrm{N})$} \\
\hline & $\begin{array}{l}\text { 粟沢地区 } \\
\text { にいる }\end{array}$ & $\begin{array}{l}\text { 網子地区 } \\
\text { lにいる }\end{array}$ & 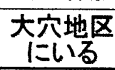 & \\
\hline $\begin{array}{l}\text { 塤汜儿地区 } \\
\text { 地区) }\end{array}$ & 95.7 & 47.8 & 43.5 & (27) \\
\hline (周接地区) & 48.4 & 96.8 & 29.0 & (38) \\
\hline $\begin{array}{l}\text { 太穴地区 } \\
\text { (䧗接地区) }\end{array}$ & 31.3 & 37.3 & 95.5 & (79) \\
\hline
\end{tabular}

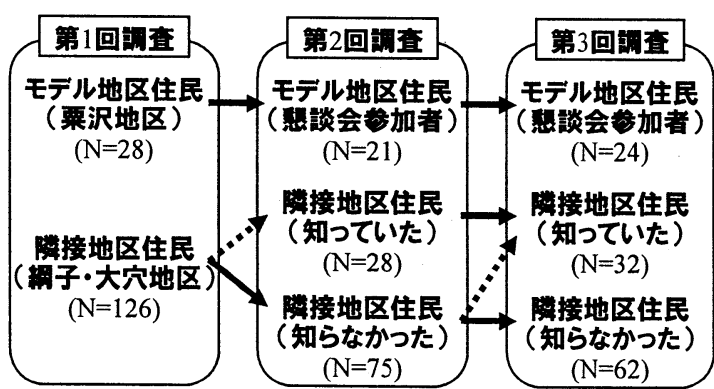

図-7 サンプルの分類

とがわかる。 


\section{（2）サンプルの分類}

前節での住民の個人属性に関する分析結果から，3 地 区間で年齢や土砂災害に対する関心，意識に大きな差は ないものと考え，モデル地区で実施した土砂災害に関す る取り組みによる効果を検証するために，図一7に示す ようなグループ分けを行った. まず，調査対象の住民を モデル地区住民と隣接地区住民の 2 つに分類する. そし て，モデル地区から隣接地区への波及効果を計測するた めに，隣接地区住民については，第 2 回調査時，第 3 回 調查時それぞれにおいてモデル地区における取り組み を『知っていた』住民と，『知らなかった』住民の 20 のグループに分類する. 以下の分析ではこの 3 分類間の 比較を行うものとする.

ここで，個人属性に着目して，土砂災害に関する意識 や行動にどのような違いがあるのかを詳細に分析する ことも重要であると考えられる. しかし, 本分析の主た る目的は，モデル地区で実施した取り組みによって，モ デル地区全体での土砂災害に対する意識や行動がどの ように変化したのか，またそのような取り組みが実施さ れていることを隣接する地区の住民が知った場合に，知 らなかった住民と比較して，どのような変化が生じるの かを検証することにある. また，対象地域の世帯数が少 数であることから，詳細な個人属性の違いを考慮した分 析に耐えうるデー夕数を確保することが困難である. そ のため，これらのことを考慮して，ここでは，先に述べ た分析目的を最優先し，図一 7 に示すように，地区を基 本単位とした分析のみを行った. なお，どのような個人， 世帯属性の住民に対して, 本研究で実施したような取り 組みが効果的であるのかを検証することは非常に重要 であると考えられるため, それについては今後の課題と したい.

また,このような事前事後比較をすることで取り組み の実施効果を計測する場合，パネルデータを用いて分析 することが最も適した方法の一つであるといえる ${ }^{12)}$ ，そ こで, 本研究においても各調査を記名式で実施し，パネ ルデータを収集することを試みた. しかし，3 回の調査 に全て記名のうえ回答してくれた住民は非常に少なか ったため, パネルデータでの分析を行うには十分なサン プル数を得ることができなかった. そのため, 本分析で は統計的な有意性を検証することが可能となるデータ 数を確保するために，無記名データや3 回の調査全てに は回答していないデータも分析データとした. すなわち 各調查時におけるクロスセッションデータを用いて分 析を行った.

\section{（3）土砂災害対応に関する意識の変化}

ここでは，土砂災害対応に関する意識の変化について みていく，調査では土砂災害対応に関する各意識項目に
ついて，「非常にそう思うから」から「全くそう思わな いの7段階で回答してもらった. これを+3から-3まで に数值化し, 各調査におけるグループ別の平均值を算出 した結果を図ー8に示す.すなわち，值が大きいほど, その項目の名称に関する意識が高いことを意味してい る.

[1]ハード施設依存について，モデル地区住民をみると， 第 1 回調查から第 2 回調查にかけては, ハード施設に対 する依存心が低下しているものの, 第3 回調査では再び ハード施設への依存心が高まっている. これは第 3 回調 査実施時には，モデル地区住民に対して防災マップが配 布されており，この防災マップの中には地域のハード施 設の整備状況も記されていることから，それを見たこと によってある種の安心感を与えてしまった可能性が考 えられる.また，隣接地区住民については，モデル地区 での取り組みを『知らなかった』グループで, 調査を重 ねるごとにハード施設への依存度が高まっているよう に見えるが, 分散分析による平均值の差の検定を行った ところ，その結果から有意な差は認められず，この項目 に関してはモデル地区での取り組みの効果の波及は見 られなかった。

[2]行政情報依存をみると，調査を重ねるごとにモデル 地区住民の行政からの情報に対する依存心が低下して いることがわかる. 分散分析による検定の結果も，それ ぞれの調査時における平均值間に有意な差が認められ たことから，懇談会による防災教育の効果があったもの と考えられる. また，モデル地区での取り組みを『知っ ていた』グループのみ，第2 回調査時において，行政か らの情報への依存心が高まっている. この理由としては， 第 2 回調查を実施した時期（平成 16 年 9 月）に全国各 地で集中豪雨や台風によって洪水や土砂㷋害が多発し ており，それに関するメディア報道で避難情報の不備を 指摘する内容が多かったために，モデル地区での取り組 みを知って, 自分たちの地域でも災害が発生する可能性 を認識したことにより，いざというときの行政からの情 報への依存心が一時的に高まったものと推察される.

[3]自助必要性についてみると，3グループともに第 1 回調查時から自助の必要性を強く認識していたことか ら変化はみられず, また統計的にも有意な差は認められ なかった. 対象地域であるみなかみ町は数年前にも土砂 災害の被害を受けている地域であるため, 多くの地域住 民は自分の身は自分で守ることの必要性は認識してい るものといえる.

[4]共助必要性についてみると，モデル地区住民では, 調査を重ねるごとに共助の必要性を強く認識するよう になっていることがわかる.これは懇談会で，災害時に は自分一人ではどうすることもできないことが多々あ り，みんなで助け合うことで地域住民全員が無事に避難 

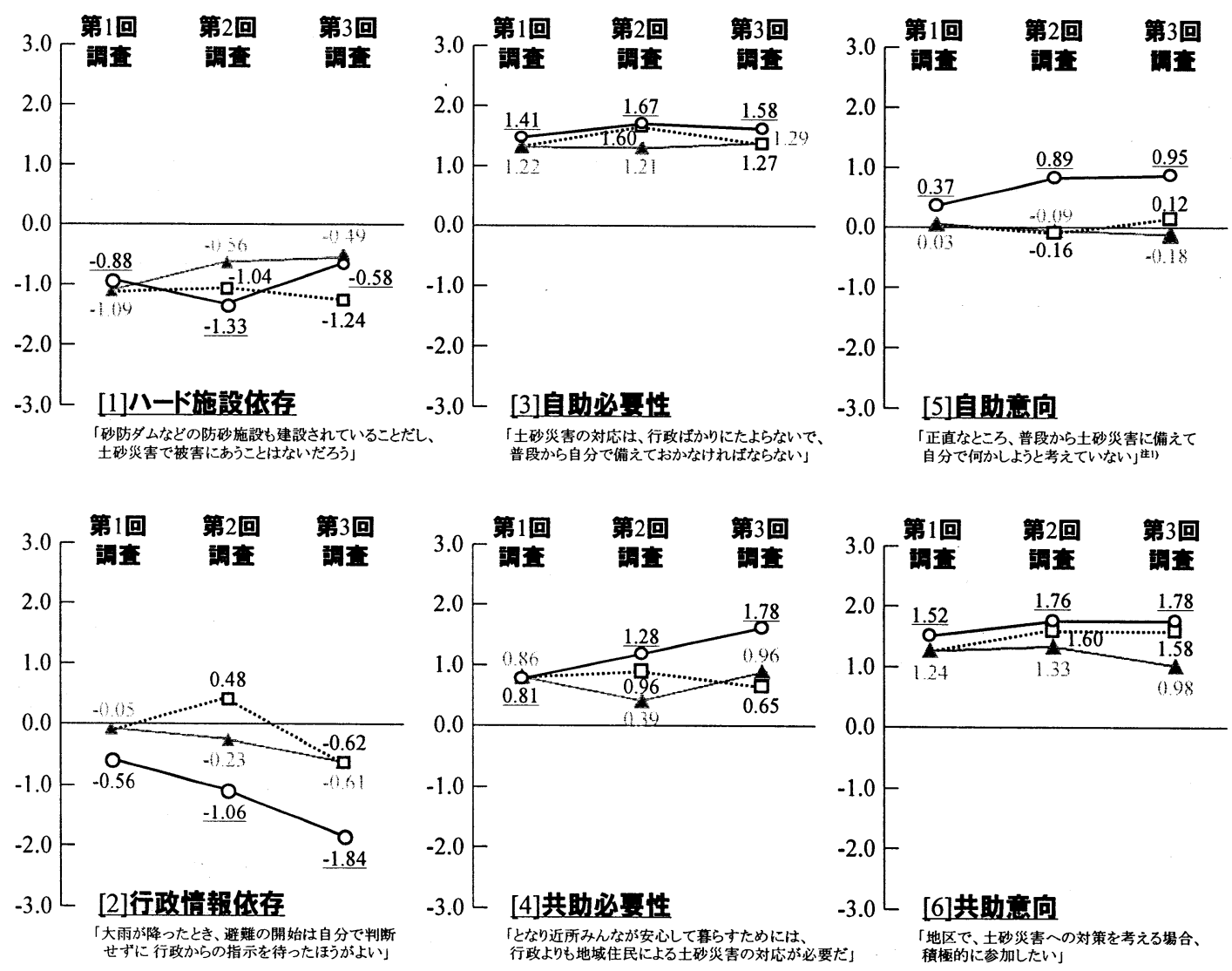

注1): 指㩩との方向性を一致させるため. 反転させて数値化した

\begin{tabular}{|c|c|c|}
\hline ー○ー モデル地区住民 & $\begin{array}{c}\text {...ロ... 隣接地区住民 } \\
\text { (知っていた) }\end{array}$ & $\begin{array}{l}\text { 隣接地区柱民 } \\
\text { (知らなかった) }\end{array}$ \\
\hline
\end{tabular}

図-8 土砂災害対応に関する意識の変化

することができる，という共助の必要性を訴えた効果で あるといえる．また，懇談会を通して地域住民が共同で 防災マップを作成するとともに，それを用いた地域住民 全員の協力が必要となるような自主避難ルールを決定 したことにより，共助の必要性はより高まったものと考 えられる。

[5]自助意向について，モデル地区住民をみると，調査 を重ねるごとに徐々に数值が上昇しており，ここから， 自分でも何か対策をしようと考える住民が増えてきた ことがわかる. これを, 前述の[3]自助必要性と比較して 考えると，ただ漠然と必要性を感じていただけの住民が， 秘談会に参加したことによって土砂災害に関する知識 を身につけ，しっかりとした理由付けから意向を持つよ うになったものと考えられる. 一方，隣接地区の 2 グル ープでは第 1 回調査から第 3 回調査までその值にほとん ど変化はみられず，自分でも何かしようという意向は形 成されなかったことがわかる.

最後に，[6]共助意向についてみると，モデル地区住民 に関しては, 調査を重ねるごとに共助意向が高まってい
ることが見て取れる. 同様に隣接地区住民のうちモデル 地区での取り組みを『知っていた』グループについてみ ると，モデル地区住民と同様に共助意向が高まっている ことがわかる.ここで『知らなかった』グループが若干 の低下傾向にあることから，モデル地区での取り組みを 知った住民は，地域での取り組みに積極的に参加しよう という意向が高まったものと考えられる.

\section{（4）日頃の備えの変化}

ここでは, 日頃の備えの変化についてみていく. 図一 9 は, 各調査時における[A]避難場所や家族との連絡方法 の確認, [B]防災訓練や防災街づくり活動への参加, [C] 地域の人たちとの検討，といった土砂災害に関する日頃 の対応行動の実施率をグループ別に示したものである.

まず, [A]避難場所や家族との連絡方法の確認について みると，モデル地区住民は特に第 1 回調査から第 2 回調 査時において大きくその実施率が上昇していることが わかる. つまり, 懇談会での防災教育により, 自助の必 要性を認識し, 自助意向が形成されたため, 災害への備 
(\%)

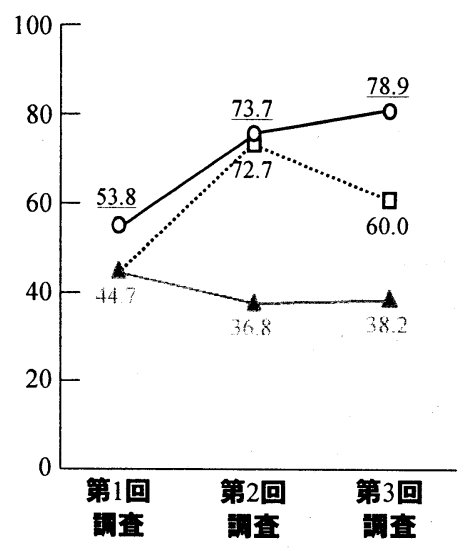

[A]避鹤場所や家族との 尰絡方法の確記
(\%)

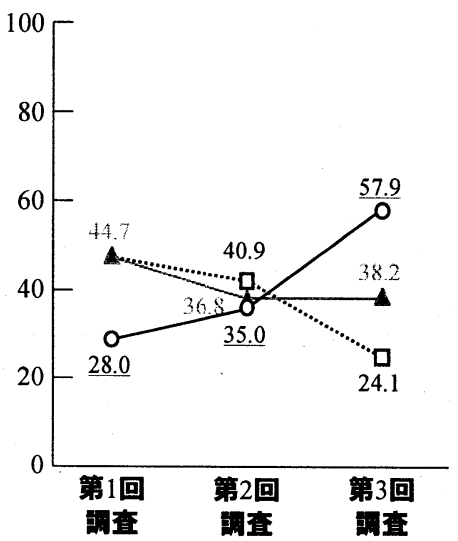

[B]防災訓綡や防炎

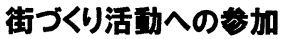

(\%)

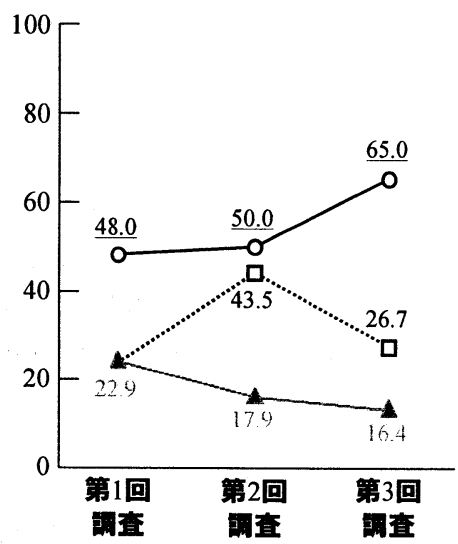

[C]地域の人たちとの榙村

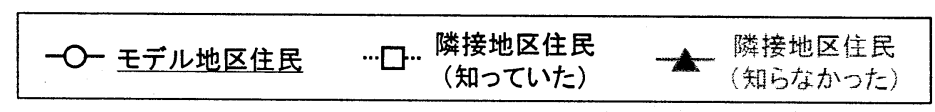

図-9 日頃の備え実施率の変化

えとして最も簡単に実施することができると考えられ る，家族との相談を誘発することができたといえる．ま た，隣接地区住民のうちモデル地区での取り組みを『知 っていた』グループをみると，第 1 回から第 2 回調査時 においてはモデル地区住民と同様に実施率が高まって いるものの, その後の第 2 回から第 3 回調査時にかけて 実施率が低下している. パネルデータを用いた分析では ないので，正確な分析はできないが，これは危機意識の 風化によるものと考えられる. しかし，第3 回調査時に おいても『知らなかった』グループより『知っていた』 グループの方が高い実施率となっていることから，モデ ル地区での取り組みの効果が波及したものといえる.

次に, [B]防災訓練や防災街づくり活動への参加につい てみると, $[\mathrm{A}]$ と同様にモデル地区住民において参加率が 高まっていることがわかる. 特にモデル地区では懇談会 を定期的に実施したため，このように高い実施率となっ たといえる. また，モデル地区での取り組みを『知って いた』グループでは, 第3 回調查においてその実施率が 他の分類と異なり，大きく低下している. 先ほども述べ たが, 本分析はパネルデータを用いた分析ではないので, 㛜密な意味で同一サンプルの変動を追跡した結果では ないため,ここでこのような低下傾向を示した原因を検 討することは難しいものと考える.このような結果とな った理由の解明は，今後も継続して観測していくなかで 明らかにしたい。

最後に, [C]地域の人たちとの検討についてみると，モ デル地区住民では特に第 2 回調査から第 3 回調査時にお いて大きくその実施率が上昇していることが見て取れ， 㨸談会での取り組みを通して，地域住民閒で積極的に災
害の対応について議論するようになったことがわかる. 一方，隣接地区住民を見ると，モデル地区での取り組み を『知っていた』グループでは, [A]と同様に第 1 回調査 から第 2 回調査時においては実施率が増加したものの, 第 2 回調查加第 3 調査時においては実施率が低下して いる. また，『知らなかった』グループは調查を重ねる ごとに実施率が低下傾向にある.

以上のことから, [A]のような自助レベルの行動につい ては，自分ひとりの意思ですぐに実行可能なため，前節 で示したように自助の必要性を認識し, 自助意向が形成 されれば, 比較的容易に行動に結びついたものと考えら れ，その効果の他地域への波及も見て取れた. しかし， [B], [C]のような共助レベルの行動については，情報を 与えられるだけの一方的な防災教育だけでなく, 実際に 地域住民が集まって，自らで何らかの対応を検討する機 会を持つことによって，実行率が上昇するものと考えら れ，そのため他地域への波及は共助レベルでの対応行動 実施率では確認されなかった. このことからも，モデル 地区で実施したような住民が集まって，地域の防災につ いて話し合う機会をつくることは重要であるといえる.

\section{5. まとめ}

本研究では，その発生を予測することが非常に困難な 土砂災害を事例に，防災教育のあり方を検討するととも に，住民主導型の自主避難体制の確立に向けた取り組み を実施し，その取り組みを通して生じた住民の態度・行 動変容を計測した. また，このような一地区を対象とし た社会実験の効果を効率的に他地域へ波及させること 
を目的として，取り組みを実施したことによる効果の波 及の実態を把握する調査を実施した. 以下に得られた成 果についてまとめる.

モデル地区での懇談会では, リスク心理学の知見を踏 まえて, 土砂災害の発生メカニズムだけでなく, 災害に 対峙した住民の心理特性を教育した. また，予測するこ とが困難な土砂災害に備えるために, 地域に言い伝えら れている伝承や過去の災害時の状況を集約し，防災マッ プを作成し，またその防災マップを用いて地域住民全員 が協力し合うような自主避難体制を組織した. そして, これらの取り組みを通じて，モデル地区住民には，八ー ド施設への依存心, 行政からの情報への依存心の改善, 自助・共助意向の上昇がみられた. そして実際の行動の 変化としても, 自助レベル・共助レベルで実施率の上昇 が確認された.

一方，隣接地区住民については，モデル地区でのこの ような取り組みを知っていた住民においては，意識面， 行動面で良好な変化がみられたものの, 時間の経過によ り意識の風化がみられた.

以上の結果から，モデル地区住民に対しては，取り組 みの効果があったと言えるだろう. 今後は，モデル地区 においては，この効果が風化することなく持続していく ことが重要であり，そのためには定期的な自主避難訓練 や防災マップの改訂などを実施していく予定である. ま た，このような取り組みに参加した住民のうち，地域の 防災活動に対して熱意のある方には，より広域な地域の 防災リーダーとして地域の防災を担う人材となるため のサポートをしていくことを検討している. 一方，隣接 地区においては，モデル住民からの情報提供のみでなく， メディアを用いた情報提供などを実施することにより 効果の波及について, 波及構造についてより詳細な分析
を行っていく.

謝辞 : 本研究の成果の一部は，砂防・地すべり技術センターより研究 開発助成を受けている.ここ記記して感期の意を表す。

\section{参考文献}

1) 片田敏孝・児玉真・桑沢敬行・越村俊一 : 住民の避難行動にみる津波 防災の現状と課題 -2003 年宮城県沖の地震・気仙沼市民意識調査加 一，士木学会論文集，No.789/II-71，pp.93-104， 2005.

2) 金井昌信・片田敏孝・吉岡环郎 : 2004.7.13新舄豪雨災㝬時にみる住民 の水害リスク認知と情報取得・伝達行動との関連分析, 日本災害情報 学会第7回研究発表大会予稿集, pp.53-60, 2005.

3) 国土交通省河川局ホームページ，豪雨災害対策緊急アクションプラ ン: http://www.mlit.go.jp/river/press/200407_12/041210/index.html, 2004.

4) 例えば, 天野篤・湯川典子：“土砂災害危急情報”に適する姿, 日本 災害情報学会第7回研究発表大会予稿集, pp.7-14, 2005.

5) 小葉竹重機・片田敏孝・古澤拓実・岩波英行 : 住民参加による土砂災 害避難システムの構築, 日本自然災害科学, Vol.22, No.4, pp.417-428, 2004.

6) 阿部真理子 ・ 目黒公郎 : 保育園の防災力向上に関寸る研究一保育園 での防苂ワークショップー, 土木学会, 第60回年次学術後年回概要集(C D-ROM), 4-001, 2005.

7) 松田曜子・系谷友宏・岡田憲夫 : 地域診断型アンケートの利用による 地域の災害対応能力向上手法に関する考察, 土木学会, 第60回年次学 術後年回概要集(CD-ROM), 4-002, 2005.

8)国連防災世界会議 HP : http://www.bousai.go.jp/wcdr/, 2005.

9) 広田すみれ・増田真也・坂上貴之 : 心理学力渵くリスクの世界, 慶應 義塾大学出版, 2002

10)片田敏孝・坚玉真・佐伯博人 : 洪水ハザードマップの住民認知とその 促進策に関する研究，土木学会水工学論文集, 第48巻, pp.433-438, 2 004.

11)吉川肇子 : リスク・コミュニケーションロ相互理解とよりよい意思決 定をめざしてロ, 福村出版, 1999.

12) 片田敏孝・及川康・杉山宗意 : パネル調査による洪水ハザードマッ プの公表効果の計測，河川技術に関する論文集，第5巻，pp.225-230， 1999.

\section{土砂災害教育のあり方とその効果・波及に関する研究}

本研究では，土砂災害を事例に防災教育のあり方を検討するとともに，住民主導型の自主避難体制の確立 に向けた取り組みを害施し，その取り組みを通して生じた住民の態度・行動変容を計測した. また，このよ うな一地区を対象とした社会実験の効果を効率的に他地域へ波及させることを目的として, 取り組みを実施 したことによる効果の波及の実態を把握した. 分析の結果, まず取り組みを実施した地区の住民については, 災害対応に関する意識に大きな改善がみられ，また自助・共助レベルでの行動変容があったことが確認され た.一方，その効果の波及についても，意識面・行動面で効果が波及していたことを確認することができた.

\section{Research on Practical Education of Sediment Disasters and its Ripple Effect *}

By Masanobu KANAI**, Toshitaka KATADA*** and Jun MOCHIZUKI****

In this study, we examined an ideal method of disaster prevention education about sediment disaster, and carried out the meeting to organize the voluntary evacuation system by residents. Then, we measured the attitude and behavior change of the residents who attended to the meeting. On the other hand, we grasped the actual situation of influence for neighboring residents who did not attended to the meeting by having carried out it, for the purpose of letting an effect of a social experiment for one such district spread to the other area effectively. 